\title{
腐食が進行した鋼矢板構造物のコンクリート 被覆による保護エに関する実証的研究
}

\author{
小林 秀一 1 ・鈴木 哲也 2 -長崎 $\quad$ 文博 3 - 佐藤 弘輝 4 \\ 1正会員＼cjkstart株式会社水倉組＼cjkstart営業本部（９９53-0041 新潟県新潟市西蒲区巻甲5480番地） \\ E-mail:s_kobayashi@mizukura.co.jp \\ 2正会員 新潟大学准教授 自然科学系（農学部）（干950-2181 新潟県新潟市西区五十嵐2の町8050) \\ E-mail: suzuki@agr.niigata-u.ac.jp \\ 3正会員 藤村ヒューム管株式会社 技術営業部（†945-0061 新潟県柏崎市栄町7-8） \\ E-mail: nagasaki@fujimura.gr.jp \\ 4正会員＼cjkstart藤村ヒューム管株式会社＼cjkstart技術営業部（†945-0061 新潟県柏崎市栄町7-8） \\ E-mail: satou.kouki@fujimura.gr.jp
}

\begin{abstract}
鋼矢板水路は作物生産基盤において広く用いられている。近年，これら構造材の長期耐久性と鋼材腐食 との関係が技術的課題として議論されている. 本研究では，腐食が進行した鋼矢板の保護工法を検討する ために鋼矢板 - コンクリート複合材の適用を検討した。実験的検討は，モデル試験と実構造物で行った。 鋼矢板 - コンクリート複合材の曲げ挙動の特性評価には, AE (Acoustic Emission) と荷重 - 変位挙動を用 いた，検討の結果，複合材の力学特性は，最大変位量と作用モーメントの関係により評価可能である. 曲 げ載荷過程での破壊挙動は，AE発生挙動と密接に関連していた。本試験結果から，鋼矢板表面にコンク リート被覆を施すことの有効性が定量的に評価できたものと推察された.
\end{abstract}

Key Words : steel sheet pile, corrosion, steel sheet pile-concrete composite, mechanical propreties, acoustic emission

\section{1. はじめに}

低平排水不良地域では，その経済性と施工性の良さか ら鋼矢板材を用いた水利施設が整備されているが，長期 供用に伴い外部環境の影響により損傷が蓄積し，既設鋼 矢板の腐食による断面欠損が維持管理において重要な技 術的課題となっている（図-1）。中でも農業水利施設は, 作物生産基盤を支えているだけではなく，湛水被害の低 減など国民の生活基盤も支える重要な社会資本となって いるが，多くの施設が戦後から高度経済成長期に集中的 に整備されたことから，更新時期を迎えており長寿命化 による効率的な保護工法の技術開発が求められている.

本論で着目する鋼矢板水路は，その多くが供用開始か ら20～40年の経過とともに鋼材腐食の進行が確認されて いる，腐食反応は，断面の減少や欠損により顕在化する が，一般的に設計段階において腐食代が設定され，腐食 後も構造安全性が確保できるように構造設計が行われて いる．農業水利施設の場合，腐食代は，一般環境におい て表裏あわせて2 mmである ${ }^{1)}$. 一般的に水の接する鋼矢 板の腐食は，鋼表面に拡散する酸素濃度に依存し2)，鋼
矢板の腐食特性に関する研究開発は1980年代を中心に港 湾構造物において多くの報告が行われている3．農業水 利施設の事例では，施工後10年から40年の鋼矢板水路を 対象に腐食状況が調査された結果, 供用から20年経過し た施設において水面付近（かんがい期と非かんがい期と で水面の高さが変動して，水面上に露出されたり水面下 に沈降したりすることが繰り返される部分）での腐食の 顕在化が報告されている4).

腐食の顕在化した鋼矢板水路は，未使用材による更新 が進められてきたが，莫大な費用を必要とするため，少

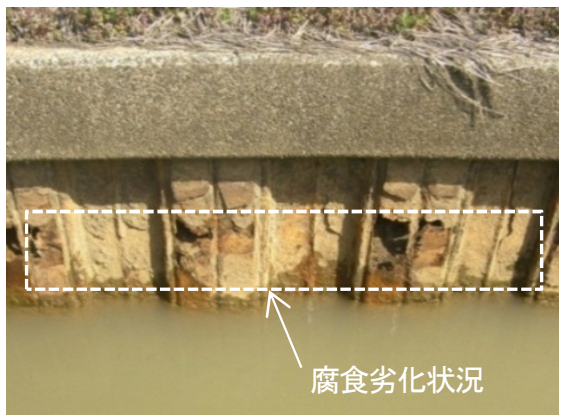

図-1 既設矢板材の腐食と断面欠損 (施工後39年施設) 
子高齢化・人口減少社会による恒常的な財政難の現状を 踏まえると現実的な解決策ではない，また，これまでは 腐食した鋼矢板表面の錆や付着物をブラスト除去した後, 防錆剤を塗布しウレタン樹脂などで被覆する表面被覆工 法が多用されてきたが，多くの施設で被覆層の剥離や紫 外線による再劣化が顕在化している（図-2）。

これらの点を踏まえて, 本研究ではLCC (Life Cycle Cost）低減の観点から優位にあると考えられるコンクリ 一トを被覆材とした表面被覆工法の適用を検討している

（図-3）．検討工法は，腐食代を有する既設鋼矢板を対 象として，コンクリート被覆による矢板材の腐食進行の 抑制と鋼矢板 - コンクリート複合材による補強効果を目 的としている.

本報では，腐食が進行した鋼矢板水路にコンクリート 被覆を施した鋼矢板 - コンクリート複合材の有効性を実 構造物と室内試験において力学特性の観点から検討した 結果を報告する. 加えて, 曲げ応力下での $\mathrm{AE} の$ 発生挙

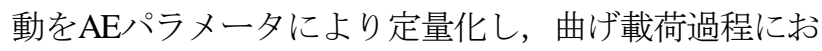
ける破壊挙動を評価した結果を報告する.

\section{2. 試験対象の施設概況}

室内試験で用いた既設鋼矢板の採取と実構造物による 現地試験は，図-4に示寸鋼矢板水路にて実施した.

試験対象である鋼矢板水路は，新潟県内に立地する供 用後30年が経過した水路幅 $2.65 \mathrm{~m}$, 水路高 $1.5 \mathrm{~m}$ 農業用 排水路である. 軽量鋼矢板（3D型，矢板長 $6 \mathrm{~m}$, 設計板 厚 $6 \mathrm{~mm}$ ）を用いた水路形式で，根入れ梁さ $4.5 \mathrm{~m}$ の自立 式矢板として護岸が構築されている. 水路諸元は, 設計 水深 $0.65 \mathrm{~m}$ （かんがい期），水路勾配 1:3000，および設 計流量 $2.831 \mathrm{~m}^{3} / \mathrm{s}$ である. 試験対象の既設鋼矢板につい ては，超音波厚さ計により鋼矢板1枚につき30箇所の板 厚測定を行い，腐食による板厚の減少状況を確認した. 測定の結果，設計板厚 $6.0 \mathrm{~mm}$ に対して，既設鋼矢板の 平均板厚 $5.2 \mathrm{~mm}$ ，板厚減少率 $13.3 \%$ \%でった．腐食に伴 う板厚減少は, 河床から $0.6 \mathrm{~m}$ の高さに位置する部位で 卓越しており（図-5），最少板厚は3.5 mmであることを 確認した. 以上から，試験対象の鋼矢板水路の腐食状況 は, 既往の研究報告4) と同様に水面付近で腐食の進行が 顕在化していることが確認された.

\section{3. 室内試験における曲げ載荷試験}

\section{(1) 試験方法}

\section{a) 供試体}

室内試験は，4ケースについて実施した．各供試体の

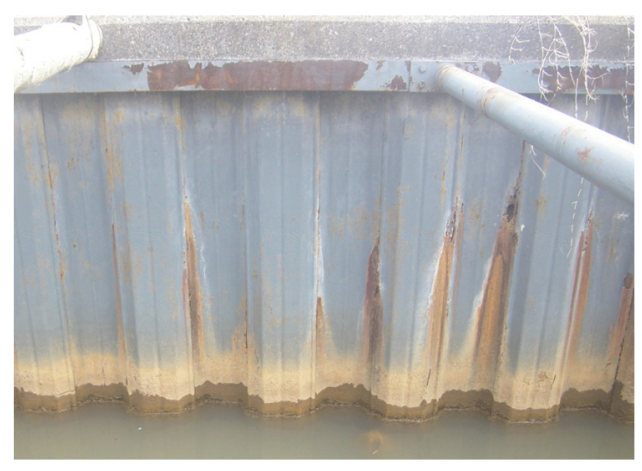

図-2 再劣化した鋼矢板水路

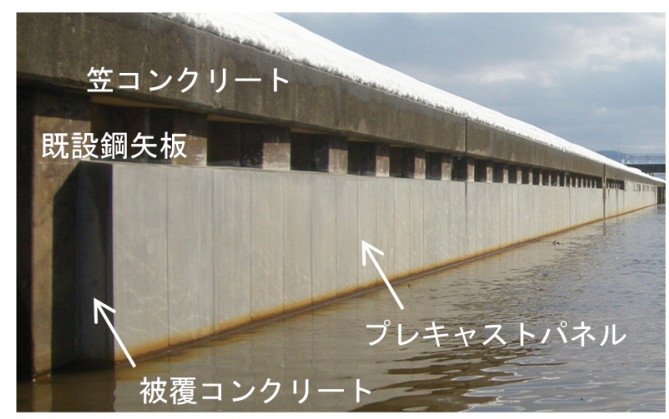

図-3 構造概念図

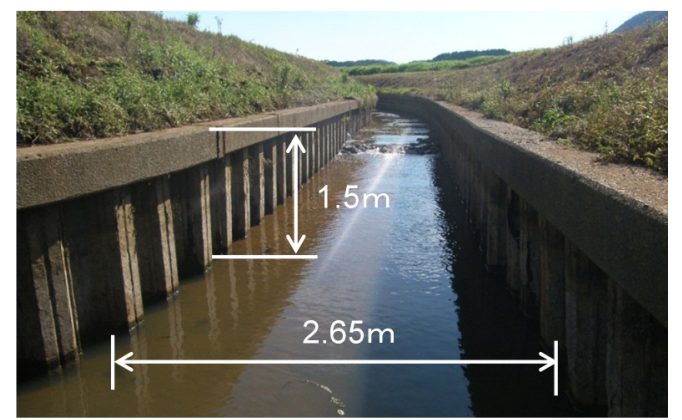

図-4 試験対象の鋼矢板水路

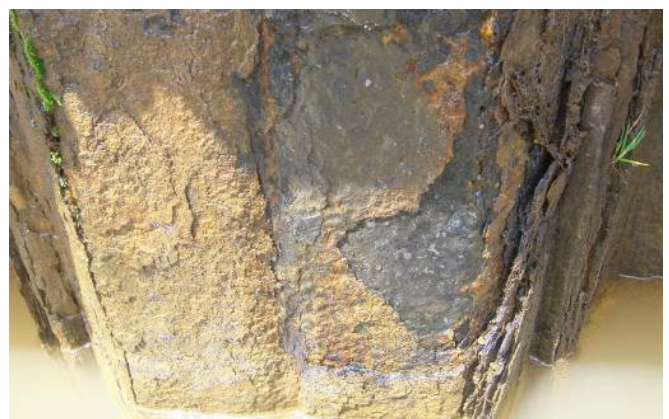

図-5 鋼矢板の腐食状況

種類を表-1，コンクリート配合を表-2，外観を図-6に示 す。鋼矢板は，実構造物から採取した既設鋼矢板と未使 用鋼矢板を用いて，それぞれ鋼矢板単材と鋼矢板にコン クリート被覆を施した鋼矢板 - コンクリート複合材の供 試体を作製した．各ケースの材料構成は，Case 1が既設 鋼矢板単材，Case 2が未使用鋼矢板単材，Case 3が既設鋼 矢板を用いた鋼矢板 - コンクリート複合材，そしてCase 
表-1 供試体の種類

\begin{tabular}{l|l|l}
\hline ケース & \multicolumn{1}{|c|}{ 種 別 } & \multicolumn{1}{c}{ 材料構成 } \\
\hline Case 1 & 既設鋼矢板 & 軽量鋼矢板 $\mathrm{t}=2.7 \sim 6.3 \mathrm{~mm}$ \\
\hline Case 2 & 未使用鋼矢板 & 軽量鋼矢板 $\mathrm{t}=5.9 \sim 6.6 \mathrm{~mm}$ \\
\hline Case 3 & 既設鋼矢板+コンクリート & 軽量鋼矢板 $\mathrm{t}=3.6 \sim 6.4 \mathrm{~mm}$, コンクリート $\sigma_{\mathrm{d}}=18 \mathrm{~N} / \mathrm{mm}^{2}$ \\
\hline Case 4 & 未使用鋼矢板+コンクリート & 軽量鋼矢板 $\mathrm{t}=5.9 \sim 6.3 \mathrm{~mm}$, コンクリート $\sigma_{\mathrm{d}}=18 \mathrm{~N} / \mathrm{mm}^{2}$ \\
\hline
\end{tabular}

表-2 コンクリート配合

\begin{tabular}{c|c|c|c|c|c|c|c|c|c|c}
\hline $\begin{array}{c}\text { 配合強度 } \\
\begin{array}{c}f_{a} \\
\left(\mathrm{~N} / \mathrm{mm}^{2}\right)\end{array}\end{array}$ & $\begin{array}{c}\text { 粗骨材の } \\
\begin{array}{c}\text { 最大寸法 } \\
\mathrm{G}_{\text {max }} \\
(\mathrm{mm})\end{array}\end{array}$ & $\begin{array}{c}\text { スランプ } \\
(\mathrm{cm})\end{array}$ & $\begin{array}{c}\text { 空気量 } \\
(\%)\end{array}$ & $\begin{array}{c}\text { W/C } \\
(\%)\end{array}$ & $\begin{array}{c}\mathrm{s} / \mathrm{a} \\
(\%)\end{array}$ & $\begin{array}{c}\text { 水 } \\
\text { W }\end{array}$ & $\begin{array}{c}\text { セメント } \\
\mathrm{C}\end{array}$ & $\begin{array}{c}\text { 細骨材 } \\
\mathrm{S}\end{array}$ & $\begin{array}{c}\text { 粗骨材 } \\
\mathrm{G}\end{array}$ & $\begin{array}{c}\mathrm{AE} \\
\text { 減水剂 }\end{array}$ \\
\hline 22 & 25 & 12.0 & 4.5 & 61.0 & 40.3 & 150 & 246 & 750 & 1128 & 2.61 \\
\hline
\end{tabular}

表-3 試験条件一覧

\begin{tabular}{|c|c|c|c|c|c|c|c|c|}
\hline \multicolumn{2}{|c|}{ 載荷サイクル } & 1 & 2 & 3 & 4 & 5 & 6 & 7 \\
\hline \multirow{2}{*}{ 荷重(kN) } & Case 1, Case 2 & 22 & 27 & 33 & 38 & 43 & 48 & 54 \\
\hline & Case 3, Case 4 & 20 & 25 & 31 & 36 & 42 & 46 & 51 \\
\hline \multicolumn{2}{|c|}{ 作用モーメント(kN ・ m) } & 18 & 22 & 27 & 31 & 35 & 39 & 43 \\
\hline
\end{tabular}

4が未使用鋼矢板を用いた鋼矢板 - コンクリート複合材 である．供試体の寸法は，鋼矢板2枚を1組とした幅 700 mm, 高さ 1500 mmで作製した. Case 3およびCase 4は, プレキャストパネル（縦 $500 \mathrm{~mm} \times$ 横 $500 \mathrm{~mm} \times$ 厚 $30 \mathrm{~mm}$ ) を所定寸法（縦 $500 \mathrm{~mm} \times$ 横 $350 \mathrm{~mm} \times$ 厚 $30 \mathrm{~mm}, 6$ 枚）に 合わせて切断加工した後, 鋼矢板の前面に配置し, 鋼矢 板とプレキャストパネルの間にコンクリートを充てんし て作製した。なお，既設鋼矢板を用いたCase 1，Case 3は， 供試体作製に先立って鋼矢板表面の錆や付着物を高圧洗 浄機（14.7 MPa）で除去している. コンクリートの厚さ は, 鋼矢板の凹凸に応じて $\mathrm{t}=125 〜 275 \mathrm{~mm}$ (パネル厚含 む）とした。コンクリートの設計基準強度は， $\sigma_{\mathrm{d}}=18$ $\mathrm{N} / \mathrm{mm}^{2}$ （材齢28日），コンクリートの種類は普通コンク リート, セメントの種類は高炉セメントB種とした。

\section{b) 曲げ載荷試験}

曲げ載荷試験の概要を図-7に示す。載荷は，供試体を 片持ち梁として実施した．載荷位置は，片持ち梁の固定 端からの載荷スパンを800 mmとした。変位挙動は，ロ ードセル（最大 $100 \mathrm{kN}$ 対応）による荷重計測と変位計 （最大変位量 $200 \mathrm{~mm}$ ）により評価した。載荷方向は, 供用時に常時土圧が作用する方向，すなわち既設鋼矢板 においては土面側, 鋼矢板 - コンクリート複合材におい ては，鋼矢板面側とした。試験条件は，表-3に示す載荷 サイクルを設定した。これは，既設鋼矢板を採取した施 設における作用モーメントをchangの式より算出し，最 大モーメントの発生点（水路底面）における設計モ一メ ント $(=18 \mathrm{kN} ・ \mathrm{~m})$ の1.5倍 $(=27 \mathrm{kN} \cdot \mathrm{m})$ を基準值とし て設定したものである. ここで，鋼矢板単材（Case 1,

Case 2）と鋼矢板 - コンクリート複合材（Case 3, Case 4)

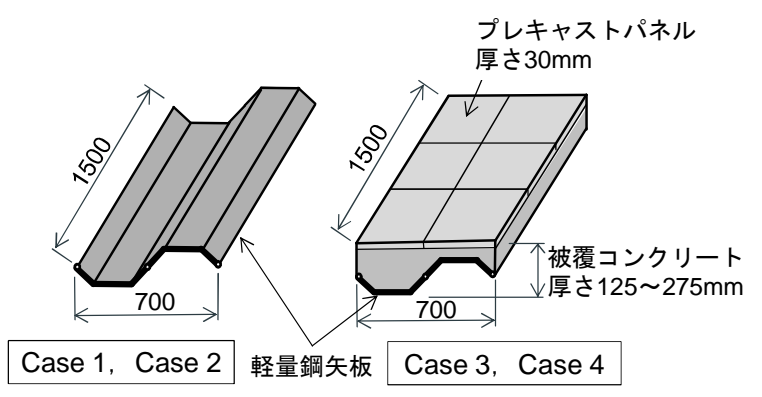

図-6 供試体外観図

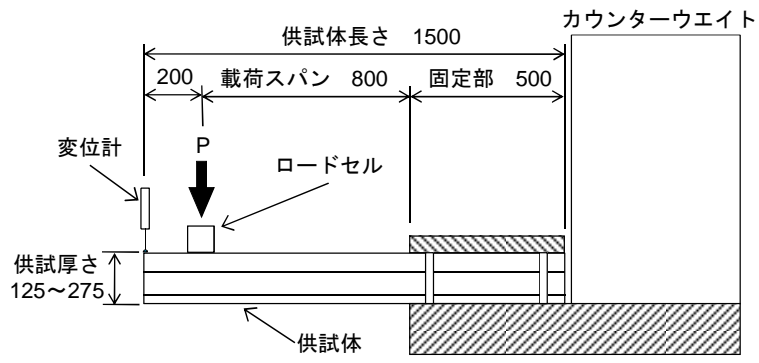

図-7＼cjkstart曲げ載荷試験概要図（Case3，Case4の場合）

で荷重条件が異なるのは，供試体を片持ち梁として設置 した際の自重モーメントの違いによるものである. 載荷 方法は繰り返し載荷とし，各サイクルで3回の載荷を繰 り返した。

c) $A E$ 計測

室内試験では，曲げ載荷過程で材料の破壊時に発生す る弾性波を $\mathrm{AE}$ 法により計測し，供試体の材料安定性評 価と $\mathrm{AE}$ 計測の有効性を検証した。AE計測は，SAMOS$\mathrm{AE}$ ンステム（PAC社製）を用いた。閾值は42 dB，検出 
波を60 dBで増幅した．AEセンサは，共振型（150 kHz） を用いて供試体の表面に8センサを等間隔に設置した.

(2) 試験結果 · 考察

a) モーメント - 変位挙動

室内試験の曲げ載荷過程における各供試体の最大変位 量の履歴を図-8, 残留変位量の履歴を図-9に示す.

鋼矢板単材では, 既設鋼矢板のCase 1と未使用鋼矢板 のCase 2で異なる変位挙動が確認された．基準となる作

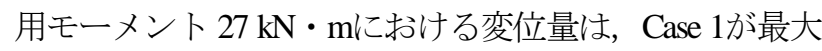
変位量 $34.3 \mathrm{~mm}$, 残留変位量 $3.1 \mathrm{~mm}$, Case 2 が最大変位量 $22.9 \mathrm{~mm}$, 残留変位量 $0.8 \mathrm{~mm}$ であった. Case 1に対する Case 2 の変位量の比は, 最大変位量 $67 \%$, 残留変位量 26\%であった.

鋼矢板 - コンクリート複合材では, 未使用鋼矢板の

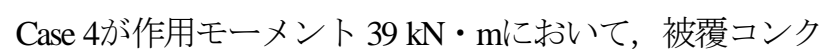
リートのひび割れが確認された（図-9）。既設鋼矢板の Case 3では，ひび割れは発生しなかった．基準となる作

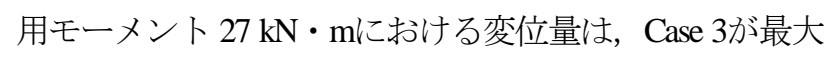
変位量 $7.3 \mathrm{~mm}$, 残留変位量 $0.9 \mathrm{~mm}$, Case 4 が最大変位量 $10.6 \mathrm{~mm}$, 残留変位量 $1.6 \mathrm{~mm}$ であった. Case 4に対する Case 3の変位量の比は, 最大変位量 $69 \%$, 残留変位量 $56 \%$ あっった.これについて, 画像解析を用いた鋼矢板 の面的な変形観察の結果，未使用鋼矢板では凹凸部にね じれを伴う変形挙動が観察された．また，2枚の鋼矢板 を1組とした供試体の継手部にずれを起因とする長手方 向の変位量の差が確認された（図-10）. Case 3に対して Case 4の変位量が大きいのは，このねじれとずれを伴う 変形挙動がCase 4の被覆コンクリートに作用したものと 考えられる.

鋼矢板単材と鋼矢板 - コンクリート複合材を比較する と, 鋼矢板 - コンクリート複合材では最大変位量の大幅 な低減が確認され，作用モーメント $27 \mathrm{kN} ・ \mathrm{~m}$ の最大変 位量は，既設鋼矢板ではCase3がCase 1に対して21\%，ま た未使用鋼矢板ではCase4がCase 2に対して46\%の結果と なった．このことから，曲げ載荷時の鋼矢板 - コンクリ 一ト複合材の変位挙動は, 被覆コンクリートに強く影響 を受けており，鋼矢板単材と比較して曲げ変形量を抑制 することが明らかになった。

\section{b) $A E$ 計測}

本研究では, 評価指標值に $\mathrm{AE} ヒ ッ ト$ 数とCalm比を用 いた。ここでAEヒット数は，一連の載荷時および除荷 時に発生するAE発生総数であり, Calm比は, NDIS2421 ${ }^{5}$ において定義されているAEパラメータである。この評 価值は,「除荷時に計数された $\mathrm{AE}$ ヒト数」に対する 「履歴のサイクル中に計数された $\mathrm{AE} ヒ ッ ト$ 数」で表さ れる.これは, 繰り返し荷重下でのAE発生挙動におい て, 載荷時に比べて除荷時の不活発さが安定性の指標と

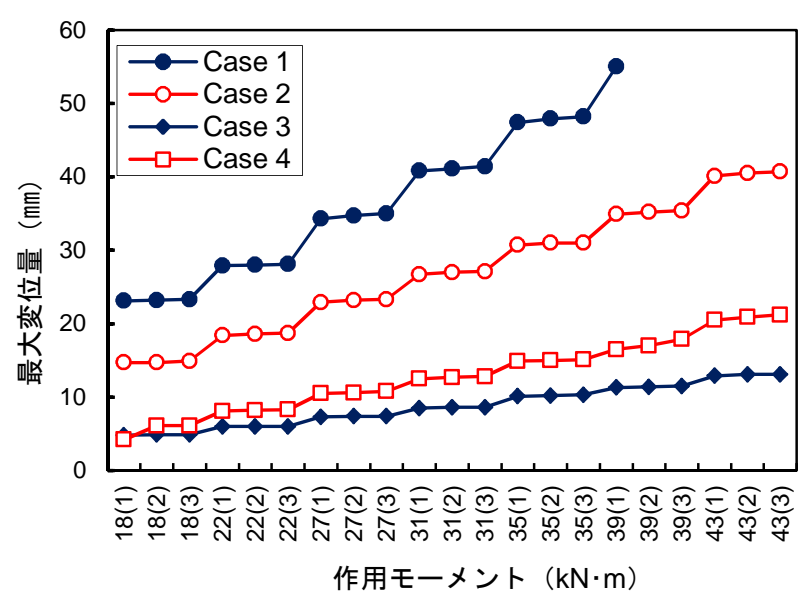

図-8 最大変位量と作用モーメントの関係

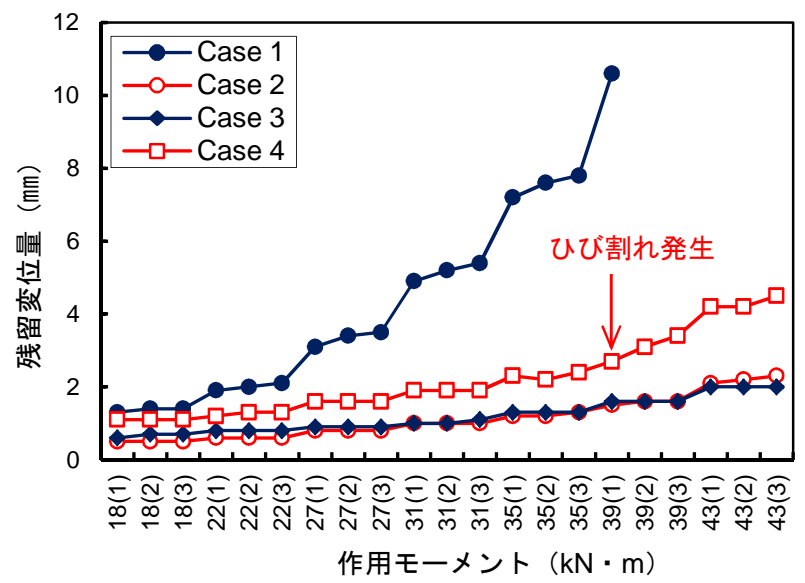

図-9 残留変位量と作用モーメントの関係

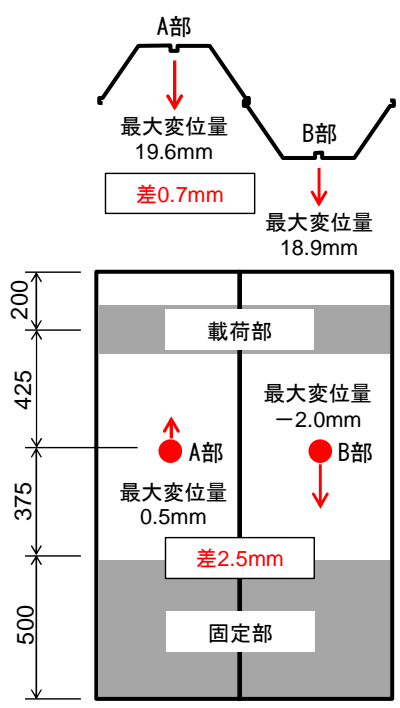

既設鋼矢板
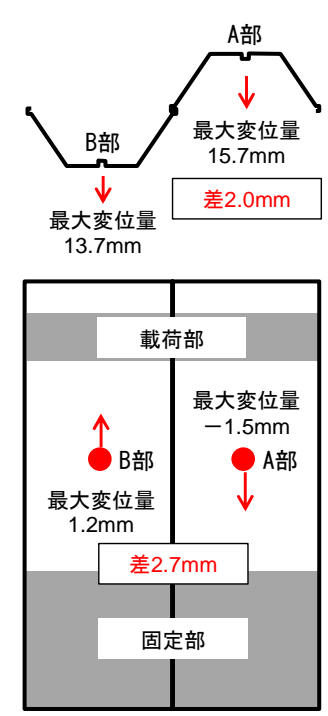

未使用鋼矢板
図-10 鋼矢板の変形観察結果

(作用モーメント $\mathrm{M}=35 \mathrm{kN} ・ \mathrm{~m}$ )

なることから，Calm比は，不活発さを健全性の指標と している. 寸なわち, Calm比の上昇は, 材料劣化を意 味しており, 本研究では, このような材料劣化が進行し 
た状態（Clam比 ○1.0）を材料の力学的安定性の低下と 定義して検討を行った.

曲げ載荷過程の作用モーメントとCalm比，残留変位

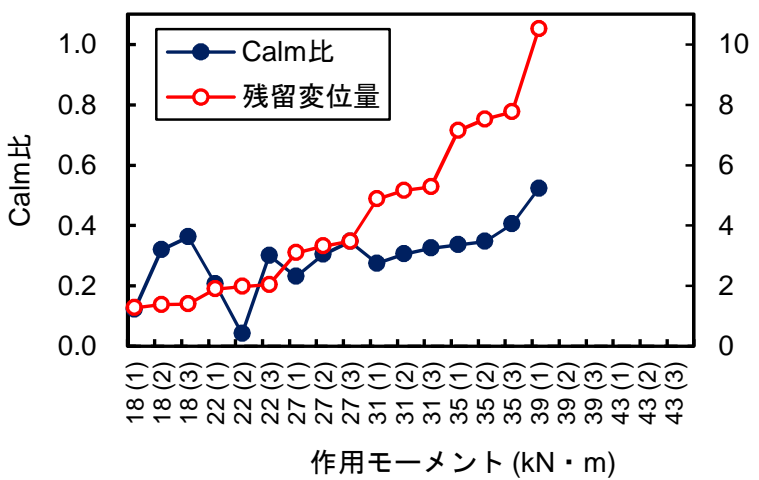

図-11 Calm比と残留変位量の関係 (Case1)

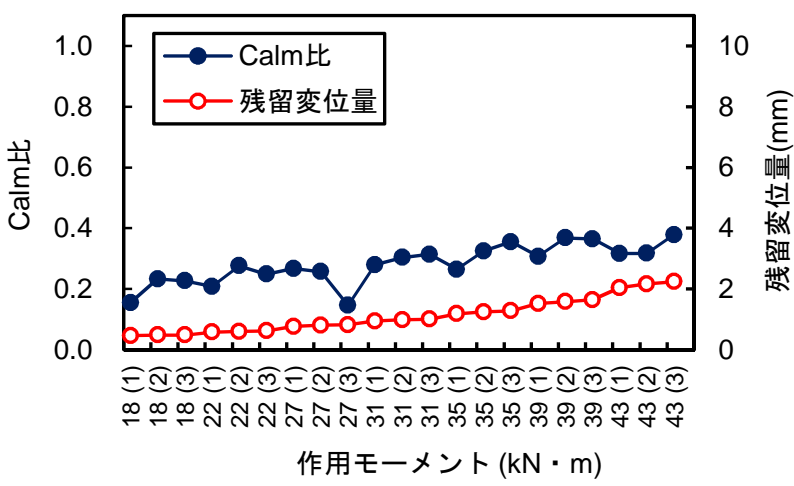

図-12 Calm比と残留変位量の関係（Case2）

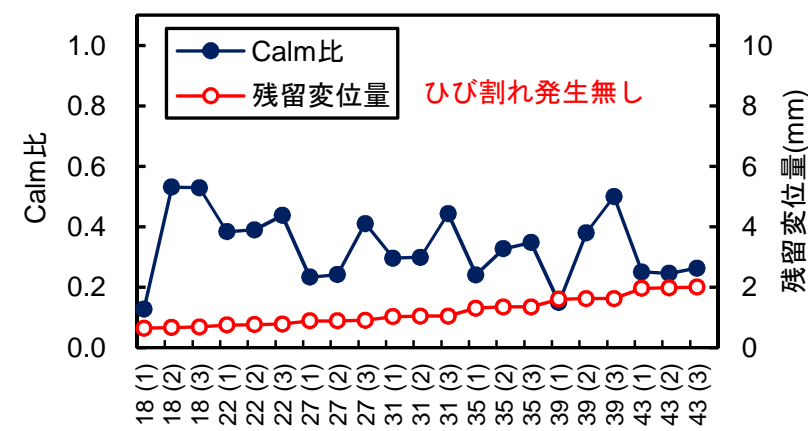

作用モーメント $(\mathrm{kN} \cdot \mathrm{m})$

図-13 Calm比と残留変位量の関係（Case3）

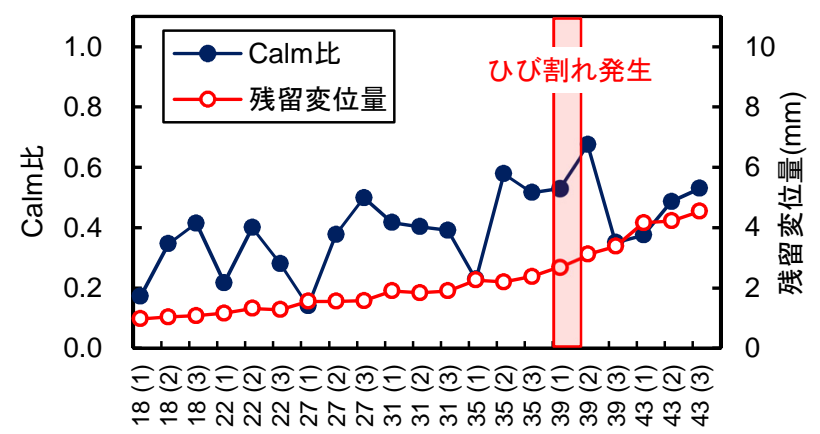

作用モーメント $(\mathrm{kN} \cdot \mathrm{m})$

図-14 Calm比と残留変位量の関係（Case4）
量の関係を図-11〜図-14に示す.

検討の結果，既設鋼矢板単材に曲げ載荷試験を行った Case 1では，Calm比の変動幅 $0.48 （ 0.04 ０ .52 ）$ ，残留変 位量の変動幅 $9.2 \mathrm{~mm}(1.3 \mathrm{~mm} \sim 10.5 \mathrm{~mm})$ が確認された. 未使用鋼矢板単材に曲げ載荷試験を行ったCase 2では, Calm比の変動幅 $0.23 （ 0.15 ０ .38 ）$, 残留変位量の変動幅 $1.7 \mathrm{~mm}(0.5 \mathrm{~mm} \sim 2.2 \mathrm{~mm})$ が確認された. 鋼矢板単材で あるCase 1およびCase 2では，作用モーメント増加に伴う Calm比と残留変位量の増加傾向が確認され, 変動範囲 に関連があることが確認された。また，Calm比と残留 変位量の変動範囲は，既設鋼矢板において大きいことが 確認され，長期供用に伴う損傷蓄積による材料安定性の 低下が示唆された.

鋼矢板 - コンクリート複合材のCase 3およびCase 4では, Case 1およびCase 2のCalm比と残留変位量の関係とは異な ることが明らかになった。既設鋼矢板の複合材に曲げ載 荷試験を行ったCase 3では，Calm比の変動幅 0.40 (0.13〜 0.53），残留変位量の変動幅 $1.4 \mathrm{~mm}(0.6 \mathrm{~mm} \sim 2.0 \mathrm{~mm})$ が確認された。未使用鋼矢板の複合材に曲げ載荷試験を 行ったCase 4では，Calm比の変動幅 $0.54 （ 0.14 〜 0.68 ）$, 残留変位量の変動幅 $3.5 \mathrm{~mm}(1.0 \mathrm{~mm} \sim 4.5 \mathrm{~mm})$ が確認さ れた. Case 3では，作用モーメント増加に伴うCalm比の 顕著な増加傾向は確認されなかったが，コンクリートに 曲げひび割れが発生したCase 4では，作用モーメント 39 $\mathrm{kN} \cdot \mathrm{m}$ でのCalm比の増加と, それ以降の作用モーメント における残留変位量の顕著な増加傾向を確認した。これ は除荷時における $\mathrm{AE}$ 頻発を意味しており，未使用鋼 矢板のねじれとずれを伴う変形挙動が被覆コンクリート に作用し力学的安定性の低下が進んだことを意味してい ると考えられる. 鋼矢板 - コンクリート複合材 (Case 3, Case4）のひび割れ発生状況を図-15に示す.

Calm比と残留変位量の関係についてまとめると，載 荷サイクル毎の残留変位量の増加とCalm比の増加には 関連があることが確認された。曲げ載荷過程における供 試体の破壊挙動の相違は，AE法により検出可能である ことが確認された。このことから，AEパラメータによ

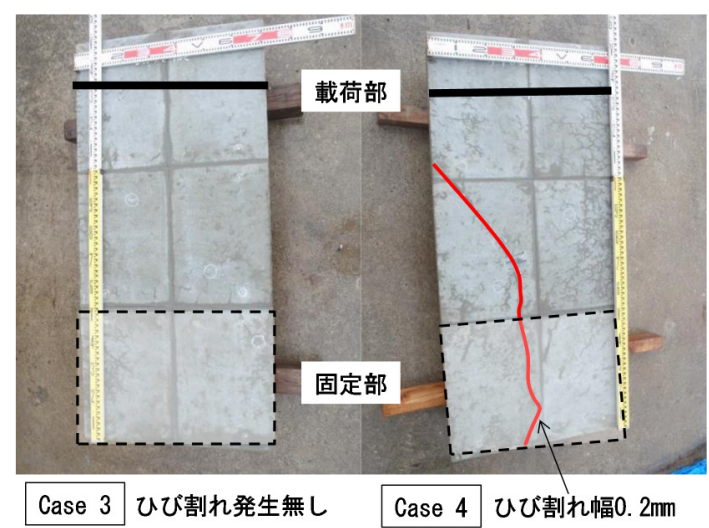

図-15ひび割れ発生状況 
表-4 供試体の種類

\begin{tabular}{l|l|l}
\hline ケース & \multicolumn{1}{|c}{ 種 別 } & \multicolumn{1}{c}{ 材料構成 } \\
\hline Case 5 & 既設鋼矢板 & 軽量鋼矢板 $\mathrm{t}=3.5 \sim 6.1 \mathrm{~mm}$ \\
\hline Case 6 & 既設鋼矢板+コンクリート & 軽量鋼矢板 $\mathrm{t}=4.0 \sim 6.5 \mathrm{~mm}$, コンクリート $\sigma_{\mathrm{d}}=18 \mathrm{~N} / \mathrm{mm}^{2}$ \\
\hline
\end{tabular}

表-5 試験条件一覧

\begin{tabular}{c|c|c|c|c|c|c|c|c}
\hline \multicolumn{2}{c|}{ 載荷サイクル } & 1 & 2 & 3 & 4 & 5 & 6 & 7 \\
\hline 荷重 $(\mathrm{kN})$ & Case 5, Case 6 & 2 & 5 & 8 & 12 & 15 & 18 & 21 \\
\hline \multicolumn{2}{c|}{ 作用モーメント $(\mathrm{kN} \cdot \mathrm{m})$} & 14 & 18 & 22 & 27 & 31 & 35 & 39 \\
\hline
\end{tabular}

る供試体の破壊挙動評価が有効であることが示唆された. 既設鋼矢板と未使用鋼矢板の面的な変形挙動の違いは, 腐食に伴う板厚減少による断面諸元の変化が大きく影響 を与えているものと推察されるが，この検討が今後の課 題である.

\section{4. 実構造物での曲げ載荷試験}

\section{(1) 試験方法}

a) 計測施設

現地試験は，供用中の鋼矢板水路を試験対象として, 既設鋼矢板単材（Case 5） と既設矢板にコンクリート被 覆を施した鋼矢板 - コンクリート複合材（Case 6）の2 一スについて実施した. 各供試体の種類を表-4に示す. 供試体は，既設水路の鋼矢板 2 枚を 1 組として隣接する鋼 矢板および笠コンクリートから独立させた。 なお，笠コ ンクリートは，残置した状態としている．供試体の寸法 は, 幅 $700 \mathrm{~mm}$, 高さ $1500 \mathrm{~mm}$ (水路渠底〜笠コンクリ 一ト天端）である. Case 6の供試体は，室内試験の供試 体と同様の工程で現地にて作製しており，鋼矢板表面を 高圧洗浄 (14.7 MPa) 処理した後, プレキャストパネル を供試体寸法に合わせて切断加工した後, 鋼矢板の前面 に配置し，コンクリートを充てんした．コンクリートの 厚さは，鋼矢板の凹ロに応じて $\mathrm{t}=125 \sim 275 \mathrm{~mm}$ (パネル 厚含む）とした。 コンクリートの設計基準強度は， $\sigma$ $\mathrm{d}=18 \mathrm{~N} / \mathrm{mm}^{2}$ （材齢28日）, コンクリートの種類は普通コ ンクリート, セメントの種類は高炉セメントB種とした.

\section{b) 曲げ載荷試験}

現地試験の概要を図-16に示す。曲げ載荷試験は，鋼 矢板の根入部を支承として自立する供試体に水平方向の 荷重を作用させて実施した，載荷位置は，笠コンクリー 卜部とし, 載荷スパンは水路渠底から $1.3 \mathrm{~m}$ とた。載 荷方向は，常時土圧が作用する土面側からセンターホー ルジャッキで載荷した，変位挙動は，ロードセル（最大 $100 \mathrm{kN}$ 対応）による荷重計測と変位計（最大変位量 200 mm)により評価した.

試験条件は，室内試験と同様にこの施設における設計

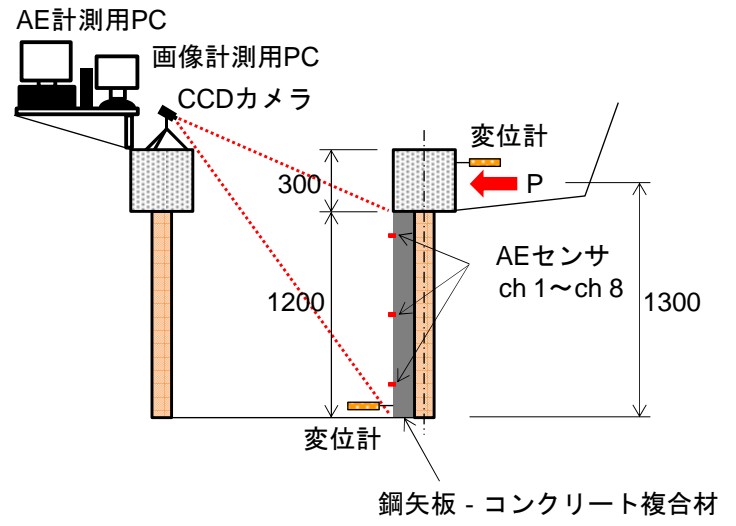

図-16＼cjkstart現地試験概要図（Case6の場合）

モーメント $(=18 \mathrm{kN} ・ \mathrm{~m})$ の1.5倍 $(=27 \mathrm{kN} ・ \mathrm{~m})$ を基準 值として表-5に示す荷重サイクルを設定した。 なお，現 地試験では，供試体に常時土圧が作用していることから， この常時土圧による作用モーメントを差し引いて載荷荷 重を算出している．載荷方法は繰り返し載荷とし，各サ イクルで3回の載荷を繰り返した。

\section{(2) 試験結果・考察}

現地試験の曲げ載荷過程における供試体の最大変位量 の履歴を図-17, 残留変位量の履歴を図-18に示す.

曲げ載荷過程において，鋼矢板 - コンクリート複合材 のCase 6に被覆コンクリートのひび割れ発生は確認され なかった. Case 6の最大変位量は, 既設鋼矢板単材の Case 5 と比較して抑制されることが確認された. 作用モ 一メント $27 \mathrm{kN} \cdot \mathrm{m}$ の荷重サイクルでの変位量を比較す ると, Case 5 が最大変位量 $22.8 \mathrm{~mm}$, 残留変位量 $2.2 \mathrm{~mm}$ あったのに対して, Case 6は最大変位量 $12.9 \mathrm{~mm}$, 残留変 位量 $3.4 \mathrm{~mm}$ であた. 自立式鋼矢板の許容変位量は, 土地改良事業計画設計基準・設計「水路工」において護 岸高 4.0 m以下では1/40と設定されている. この施設の護 岸高は1.5 mであることから, 許容值は37.5 mmとなる. 本試験結果は，作用モーメント $27 \mathrm{kN} ・ \mathrm{~m}$ の荷重サイク ルにおいて, Case 5, Case 6のいずれも許容值を下回って いた.しかし，Case 5に対してCase 6は最大変位量で9.9 mm減少しており, 鋼矢板 - コンクリート複合材では載 荷過程において曲げ変形量を抑制する効果が働いたもの 
と考えられる. しかし，残留変位量では，Case 6がCase 5 に比べ大きいことが確認された。このCase 6の残留変位 量の増加傾向は，作用モーメント $27 \mathrm{kN} ・ \mathrm{~m}$ を超えた載 荷サイクルから顕著に表れ始めている．作用モーメント $27 \mathrm{kN} ・ \mathrm{~m}$ 以降の荷重サイクルにおいてCase 5とCase 6の残 留変位量の差が拡大傾向を示寸理由として, 被覆コンク リートによる重量増加が，鋼矢板水路の設計荷重を大き く超えた水平荷重に対する鋼矢板の根入れ以深の変位量 を増加させたものと考えられる，通常，実工事では出来 形管理基準值が定められており ，鋼矢板施工時の許容 変位量は1/100以下となっている。この施設の護岸高は $1.5 \mathrm{~m}$ であることから，許容值は $15 \mathrm{~mm}$ となる．本試験結 果は，作用モーメント $27 \mathrm{kN} ・ \mathrm{~m}$ の荷重サイクルにおい て，Case 5の残留変位量は3.4 mmであり，許容值を下回 っており，実工事一の適用の観点からは問題ないと考え られる。

\section{5. 補修鋼矢板の腐食モニタの試み}

本研究で検討しているコンクリートを被覆材とした表 面被覆工法は，施工後に内部の鋼矢板の腐食進行が抑制 されたかどうか直接目視できなくなる。一般的にコンク リート中の鋼材はアルカリ環境下にあるため，腐食の進 行は抑制される。しかし，土袞とコンクリートとを跨っ て鋼材が設置されている場合に，コンクリートと土壤と の境界部で，コンクリート中の鋼材部分がカソード，土 壤中の鋼材部分がアノードとなるマクロセルが形成され, 土袞との境界部のアノード部を中心に鋼材の腐食が促進 される可能性がある。この腐食機構は，コンクリート/ 土壤系マクロセル腐食（以下，C/S マクロセル腐食と 称す）と定義されており》，急速な腐食が発生する可能 性が高いため，検討工法を適用した施設において時系列 変化を検証する必要がある。本研究では，C/Sマクロ セル腐食の可能性を定量的に評価寸るため，判定の指標 となる電位計測を試みた。電位計測は，鋼材腐食度モ二 ター（型式：MIN-091-0 米国MCM社製）を用いた。こ の機器により，既設鋼矢板に設置した計測用リード線と 笠コンクリート部の照合用電極を接続し，両極間の電位 差を計測した（図-19）。計測用リード線は，左右岸と もに鋼矢板-コンクリート複合材の底版から $500 \mathrm{~mm} の$ 高 さの既設鋼矢板表面に設置した。計測電位による $\mathrm{C} / \mathrm{S}$ マクロセル腐食の判定は，電位が-400 mVより大きい場 合に，腐食の発生をもたらす C/S マクロセル形成の可 能性があると判定した ${ }^{8)}$ 。検討工法を適用した施設にお ける電位計測結果を図-20に示寸，電位の初期値は，既 設鋼矢板にコンクリートを被覆する直前に計測した。 検討の結果，右岸側については初期值（-389 mV）を超

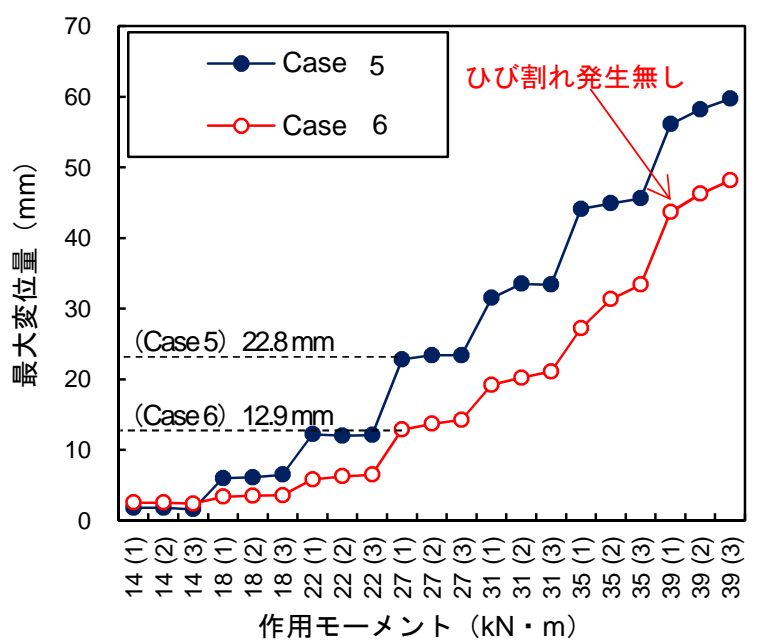

図-17 最大変位量と作用モーメントの関係

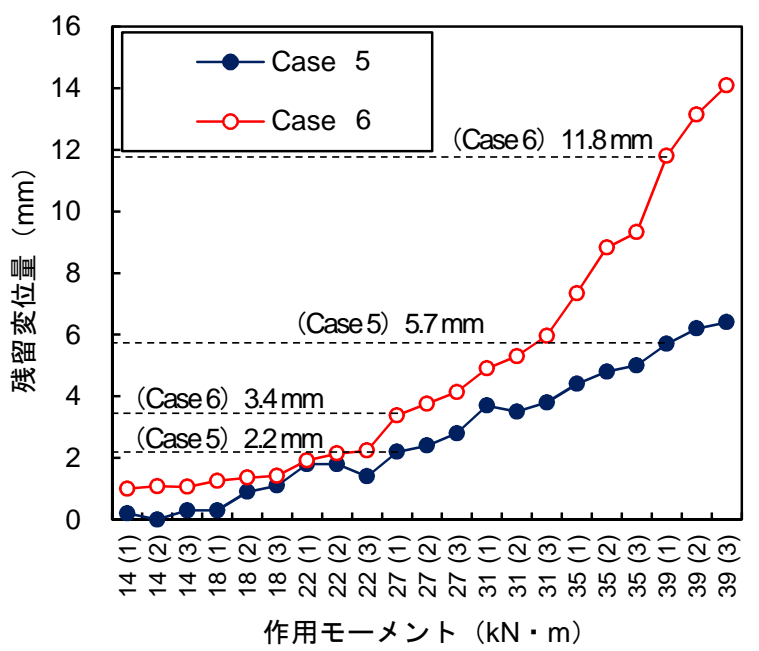

図-18 残留変位量と作用モーメントの関係

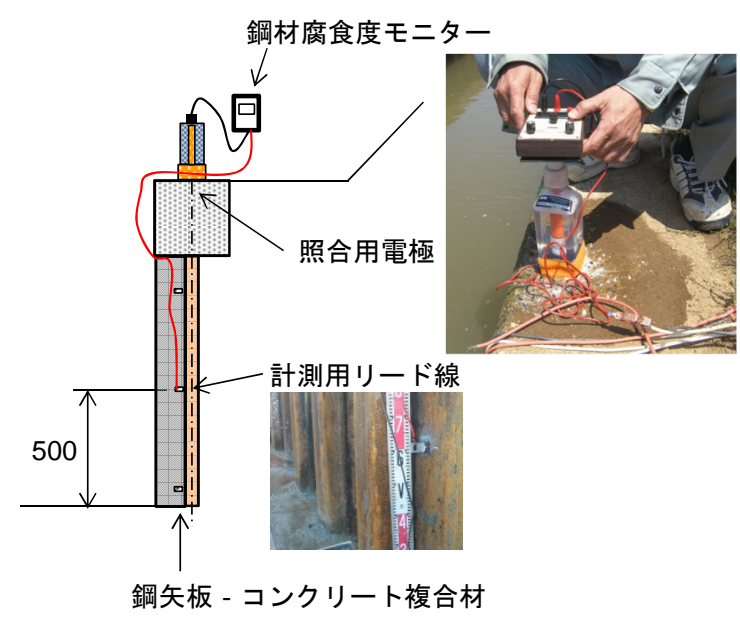

図-19 電位計測の概要

える值が3月の計測值 $(-359 \mathrm{mV})$ において確認されたが, それ以外は初期值より小さく $-400 \mathrm{mV}$ 超える值は計測 されなかった．また，左岸側については計測期間を通し て初期値 (-571 mV) より小さい值が計測された. 左右 岸とも既設鋼矢板にコンクリートを被覆した後も電位と 
計測期間の関係は，ほぼ一定であったことから，適用前 と比較してC/S マクロセル腐食の発生確率に変動は無 いものと推察される．ただし，計測期間が供用後約16ケ 月と短期間であることから，今後も詳細な観察を通して， 検討工法の有効性を検証する計画である。

\section{6. おわりに}

本報では，腐食が進行した鋼矢板水路にコンクリート 被覆を施した鋼矢板 - コンクリート複合材の有効性を実 構造物と室内試験において力学特性の観点から検討した. 加えて, AE法により曲げ載荷過程における破壊挙動を 検討した．検討結果を以下に列挙する.

（1）室内試験より，曲げ載荷時の鋼矢板 - コンクリート 複合材の変位挙動は，被覆コンクリートに強く影響 を受けており，鋼矢板単材と比較して曲げ変形量を 抑制することが明らかになった。

（2）室内試験における供試体の破壊挙動を $\mathrm{AE}$ パラメー タにより検討した結果，既設鋼矢板の長期供用によ る損傷蓄積に伴う材料安定性の低下が確認された。 また，鋼矢板 - コンクリート複合材の曲げ載荷過程 における供試体の破壊挙動の相違は，AE法により 検出可能であることが確認された.

（3）現地試験より，曲げ載荷時の鋼矢板 - コンクリート 複合材の曲げ変形量は，土地改良設計基準に基づく 自立式矢板に対する許容変位量の基準值を下回ると ともに，鋼矢板 - コンクリート複合材による最大変 位量の抑制効果が確認された。

（4）検討工法を適用した施設においてC/Sマクロセル 腐食の可能性を定量的に評価した結果，適用前と比 較してC/S マクロセル腐食の発生確率に変動は無 いものと推察される.

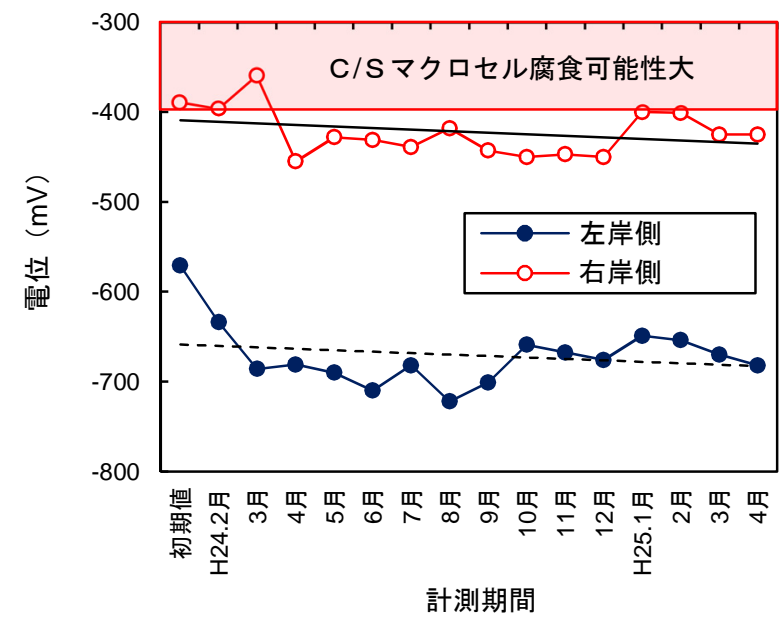

図-20 計測電位の時系列変化

\section{参考文献}

1) 農林水産省農村振興局整備部設計課：土地改良事業 計画設計基準・設計「水路工」技術書，（社）農業 農村工学会, pp.357-374, 2001.

2）松下踇：自然環境における腐食，金属表面技術，Vol. 3, No. 7, pp.383-392, 1980.

3) 溝口茂, 山本一雄, 杉野和男, 沢井章 : 半世紀経過 した護岸用鋼矢板の腐食挙動, 防食技術, 36, pp.148-156, 1987. 03.

4) 鈴木哲也, 森井俊広, 原斉, 羽田卓也 : 地域資産の 有効活用に資寸る鋼矢板リサイクル工法の開発，農 業農村工学会誌，80（10）， pp. 21 - 24，2012.10.

5) 日本非破壊検查協会：NDIS2421 コンクリート構造物 のアコースティック・エミッション試験方法, 2000.

6) 国土交通省港湾局監修 : 港湾工事共通仕様書, pp.1718, 2012.

7) 農林水産省農村振興局整備部設計課：土地改良事業 計画設計基準・設計「パイプライン」技術書，（社） 農業農村工学会, p.412, 2009.

8）防食委員会：マクロセル腐食防食指針 WSP 045-2008, 日本水道鋼管協会, pp.26-27, 2008.

(2013. 7. 12 受付)

\section{CONSERVATION OF CORRODED STEEL SHEET PILE USING CONCRETE COATING}

\section{Shuichi KOBAYASHI, Tetsuya SUZUKI, Yasuhiro NAGASAKI and Kouki SATO}

A large number of the steel sheet pile canal has been widely used in rural areas. In recent years, the relationship between the durability and the corrosion of the steel sheet pile has been discussed as a technical problem. In this study, development of conservation method for corroded steel sheet pile is going to be performed, applying steel sheet pile - concrete composite. The experiments were conducted in model tests and existing structure. In the monitoring, the bending properties of composites are evaluated based on AE (acoustic emission) and load-displacement relations. Thus, the mechanical properties could be evaluated by comparing a moment with a maximum displacement, which is analyzed by mechanical properties. A relation between mechanical value and composite properties are correlated. The AE generation behavior is correlated with fracture process in bending test, and thus the covering effect of concrete is quantitatively estimated. 